\title{
Study of Neuropteroidea (Raphidioptera, Neuroptera) Communities by Using Malaise Traps in an Untreated Orchard and its Environment
}

\author{
J. VAS ${ }^{1}$, V. MARKÓ ${ }^{1}$, L. ÁBRAHÁM ${ }^{2}$ and Z. MÉSZÁROS ${ }^{1}$ \\ ${ }^{1}$ Department of Entomology, Szent István University, Budapest, Hungary \\ ${ }^{2}$ Somogy County Museum, Kaposvár, Hungary
}

\begin{abstract}
Neuropteroidea communities were studied near Budapest (Nagykovácsi) in an abandoned, mixed orchard and its neighbouring environment: a shrub community without a closed canopy; a shrub level of the canopied oak forest by using Malaise traps.

In the open shrub verge of the orchard larger, and in the oak forest more diverse Neuropteroidea community developed than in the other investigated habitats.

The Neuropteroidea communities studied did not show stable compositions in the investigated habitats and years.

By studying the linkage conditions of different species to different habitats, it was established that Hypochrysa elegans was strongly bound to the shrub level of the closed oak forest. Besides that, both in the shrub level and in the open forest edge, the species Micromus lanosus, Micromus angulatus, Hemerobius micans, Hemerobius lutescens and Hemerobius humulinus were found with higher density. The species Dichrostigma flavipes, Chrysopa formosa, Chrysopa perla, Xanthostigma xanthostigma, Chrysoperla carnea and Dichochrysa prasina occurred in all three habitats, thus they have to be regarded as habitat generalists. By passing beyond these tendencies Dichrostigma flavipes, Chrysopa formosa and Chrysopa perla seemed to be more attached to the shrubby edge.
\end{abstract}

Keywords: Raphidioptera, Neuroptera, habitat preference, orchard, oak forest.

Many papers have dealt with the habitat preference of Neuroptera (Killington, 1936; Aspöck et al., 1980; Duelli, 1980a, 1980b; Altieri and Todd, 1981; Zeleny, 1984; Szentkirályi, 1989, 1992a). By considering the importance of study of Neuropteroidea communities, investigations were started to detect, which factors can be either

a) internal, determined by physiological and genetical causes like feeding habits, readiness for dispersion (Duelli, 1980a, 1980b) and

b) external, biotic and abiotic environmental factors (Honek, 1981). A part of these external factors determined the composition of the surrounding vegetation and connected phytophagous elements, as potential prey animals. In natural, diverse habitats large neuropteroid communities, which contain many species, can be formed (Honek, 1981; Monserrat and Martín, 1994, 1996; Sziráki, 1996). In agro-ecosystems (both in hard- and soft wooded ones) generally poorer neuropteroid communities, that contained however large individual numbers and whose continuous, gradual growth resulted from the natural capacity of edge habitats to produce diverse species, have been found (Szabó and Szentkirályi, 1981; Szentkirályi, 1989, 1992b; Paulian and Andriescu, 1996).

The authors of the present paper wanted to study this edge effect in the surrounding of mixed, non-cultivated orchard and wanted to obtain answers to the following questions: 

rent habitats;

- which species and in what individual densities of neuropteroids occur in diffe-

- what are the similarities and differences in the compositions of neuropteroid assemblages occurring in different habitats;

- how closely are different species connected to different habitats.

In the course of our studies we used Malaise traps that are especially suitable to collect flying insects, although they are mostly recommended to catch Diptera and Hymenoptera species. Móczár (1967) and Roberts (1970) considered the Malaise traps useful in determining the characteristic species of insect faunas and in giving a comprehensive view on insect communities - due to their uninterrupted, day and night functioning. Juillet (1963), Móczár (1967), Moed and Heads (1987) in their observations found the number of neuropteroids rather limited, whereas Vidlicka $(1994,1995)$ found these traps suitable for collecting Neuropteroidea.

\section{Materials and Methods}

Our studies have been carried out at the 2-hectare abandoned mixed orchard of the Research Institute of Plant Protection of the Hungarian Academy of Sciences near Budapest, in Nagykovácsi (Júlianna-major). Ten years before the beginning of present study also the chemical weed control of the orchard was terminated and discontinued.

In the untreated plantations and in their surroundings three Townes type Malaise traps were installed. As all the three belonged to the same type, it was supposed that their effects in distorting the catching result were also similar, therefore negligible in the comparisons. The traps used were made of a white 2.0-millimetre mesh, so they were unsuitable for collecting Coniopterygids. The catching surface of the trap wings amounted to 10 $\mathrm{m}^{2}$ in total, the one of the cylinder jacket $15 \mathrm{~m}^{2}$.

The first trap was placed into the middle of the orchard, into an open spacing between two rows of pear and prune trees; the second was set into the $30 \mathrm{~m}$ wide open space between the plantation and the neighbouring oak forest, that was covered by diverse low shrubs. The third trap was set at a distance of $100 \mathrm{~m}$ into the mixed, canopied oak forest (Querceto-petreae-cerris and Ceraso petreae pubescentis). The traps were operated in 1991 and 1992 from mid-April until early October and were emptied three times weekly.

In the course of processing the data of the collected material the diversity values were calculated by using the Rényi diversity formula (RTS) (Tóthmérész, 1995); the similarities were calculated by metric ordination, by principal co-ordinate analysis (PCoA) and by using the Horn and Jaccard indexes.

\section{Results}

In course of two years 410 individuals of 25 species were collected in total (Table 1). The Neuropteroidea communities showing the highest abundance were formed on the edges; 1.5-2 times higher than in the oak forest and in the orchard (Table 1, Fig. 1). 
Considering the number of species, the richest community appeared in the forest and on the edge whereas the lowest species number was observed in the orchard itself in both study years (Table 1, Fig. 1).

\section{Table 1}

Number of different Neuropteroidea species collected in an untreated, mixed orchard, neighbouring open, bushy edge and a shrub level of an oak forest Nagykovácsi,

Hungary, 1991-1992, Malaise trapping

\begin{tabular}{|c|c|c|c|c|c|c|}
\hline Species & $\begin{array}{c}\text { Forest } \\
1991 \\
\end{array}$ & $\begin{array}{l}\text { Edge } \\
1991 \\
\end{array}$ & $\begin{array}{c}\text { Orchard } \\
1991 \\
\end{array}$ & $\begin{array}{c}\text { Forest } \\
1992 \\
\end{array}$ & $\begin{array}{l}\text { Edge } \\
1992 \\
\end{array}$ & $\begin{array}{c}\text { Orchard } \\
1992 \\
\end{array}$ \\
\hline Chrysopa formosa Brauer & 1 & 7 & 0 & 4 & 10 & 5 \\
\hline Chrysopa pallens Rambur & 0 & 0 & 0 & 0 & 4 & 2 \\
\hline Chrysopa perla Linnaeus & 2 & 13 & 15 & 9 & 58 & 14 \\
\hline Chrysopa walkeri McLachlan & 0 & 0 & 1 & 0 & 0 & 0 \\
\hline Chrysoperla carnea Stephens & 1 & 7 & 4 & 8 & 4 & 9 \\
\hline Cunctochrysa albolineata Killington & 0 & 0 & 0 & 2 & 0 & 0 \\
\hline Dichochrysa flavifrons Brauer & 0 & 0 & 0 & 1 & 0 & 0 \\
\hline Dichochrysa prasina Burmeister & 3 & 7 & 6 & 13 & 3 & 14 \\
\hline Dichrostigma flavipes Stein & 12 & 18 & 3 & 0 & 7 & 4 \\
\hline Hemerobius humulinus Linnaeus & 2 & 7 & 0 & 3 & 1 & 0 \\
\hline Hemerobius lutescens Fabricius & 5 & 10 & 0 & 2 & 2 & 0 \\
\hline Hemerobius micans Olivier & 1 & 0 & 0 & 6 & 2 & 1 \\
\hline Hypochrysa elegans Burmeister & 2 & 0 & 0 & 7 & 1 & 0 \\
\hline Inocellia crassicornis Schummel & 0 & 0 & 1 & 0 & 0 & 0 \\
\hline Micromus angulatus Stephens & 5 & 2 & 0 & 2 & 2 & 2 \\
\hline Micromus lanosus Zeleny & 4 & 4 & 0 & 9 & 4 & 1 \\
\hline Micromus variegatus Fabricius & 0 & 0 & 0 & 0 & 0 & 1 \\
\hline Nineta flava Scopoli & 0 & 0 & 0 & 1 & 0 & 0 \\
\hline Parainocellia braueri Albarda & 0 & 0 & 1 & 0 & 0 & 0 \\
\hline Raphidia ophiopsis Linnaeus & 0 & 0 & 0 & 2 & 0 & 2 \\
\hline Subilla confinis Stephens & 0 & 0 & 0 & 1 & 3 & 4 \\
\hline Sympherobius elegans Stephens & 1 & 1 & 0 & 0 & 0 & 0 \\
\hline Sympherobius pygmaeus Rambur & 0 & 3 & 0 & 0 & 0 & 0 \\
\hline Wesmaelius subnebulosus Stephens & 0 & 2 & 0 & 0 & 0 & 0 \\
\hline Xanthostigma xanthostigma Schummel & 4 & 5 & 4 & 0 & 4 & 7 \\
\hline Number of individuals & 43 & 86 & 35 & 70 & 105 & 66 \\
\hline Number of species & 13 & 13 & 8 & 15 & 14 & 13 \\
\hline
\end{tabular}

Table 2

Comparison of the Rényi diversities of the Neuropteroidea assemblages of the different studied habitats at different scale parameters by t-test

\begin{tabular}{lcccccc}
\hline & 1 & 2 & 3 & 4 & 5 & 6 \\
\hline Forest - Edge & $4.28^{* *}$ & $5.24^{* *}$ & $5.78^{* *}$ & $5.87^{* *}$ & $5.69^{* *}$ & $5.42^{* *}$ \\
Forest - Orchard & $4.09^{* *}$ & $4.42^{* *}$ & $4.19^{* *}$ & $3.88^{* *}$ & $3.61^{* *}$ & $3.39^{* *}$ \\
Edge - Orchard & 0.33 n.s. & 0.68 n.s. & $1.19^{*}$ n.s. & 1.39 n.s. & 1.45 n.s. & 1.46 n.s. \\
\hline
\end{tabular}

t values; ${ }^{* *} \mathrm{p}<0.001$, n.s. - non-significant 


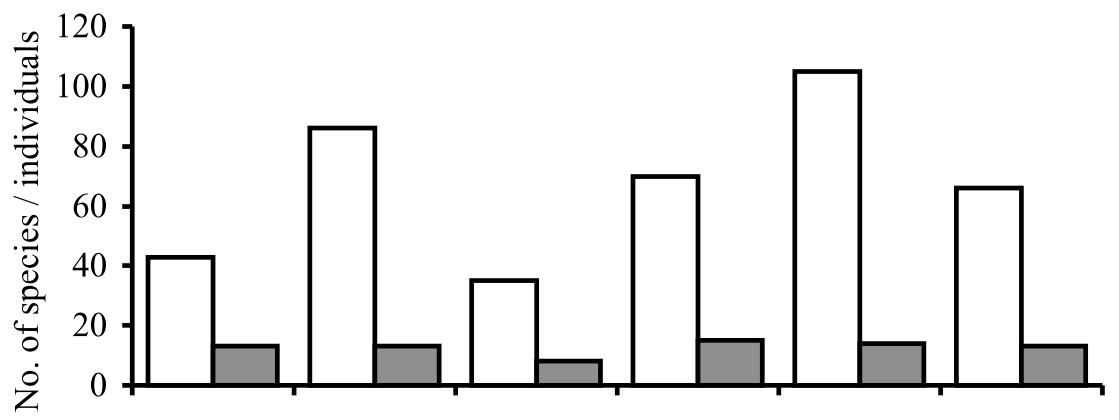

Forest 91 Edge 91 Orchard 91 Forest 92 Edge 92 Orchard 92

\section{口Number of individuals $\quad$ aNumber of species}

Fig. 1. Development of density and species richness of Neuropteroidea communities in an untreated, mixed orchard, neighbouring open, bushy edge and a closed, canopied oak forest

By studying the diversities and by drawing together the data of the two years it was established that the community appearing at the shrub level of the oak forest has been more balanced and for the whole length of the scale parameter more diverse than the Neuropteroidea communities of other habitats (Fig. 2). The differences between the forest and the edge were significant in the total length of the scale parameter (Table 2, Fig. 2).

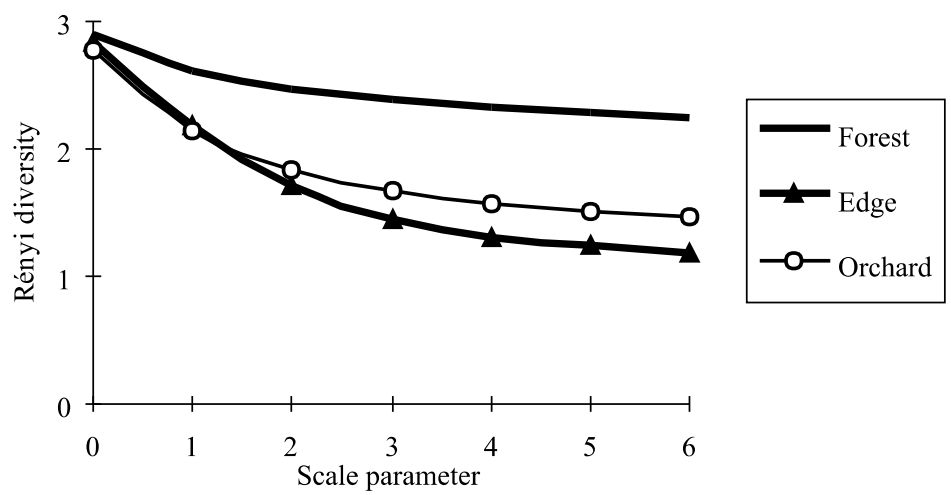

Fig. 2. Rényi diversities of neuropteroid communities, collected by Malaise traps in an abandoned, mixed orchard, neighbouring open, bushy edge and in the shrub level of an oak forest,

Nagykovácsi, Hungary, 1991-1992

By studying the similarities (Horn index) it has been established that in different habitats and different years and considering the species composition and also the dominance conditions, no really characteristic communities have been segregated (Fig. 3). The comparison by Jaccard index showed similar results. 


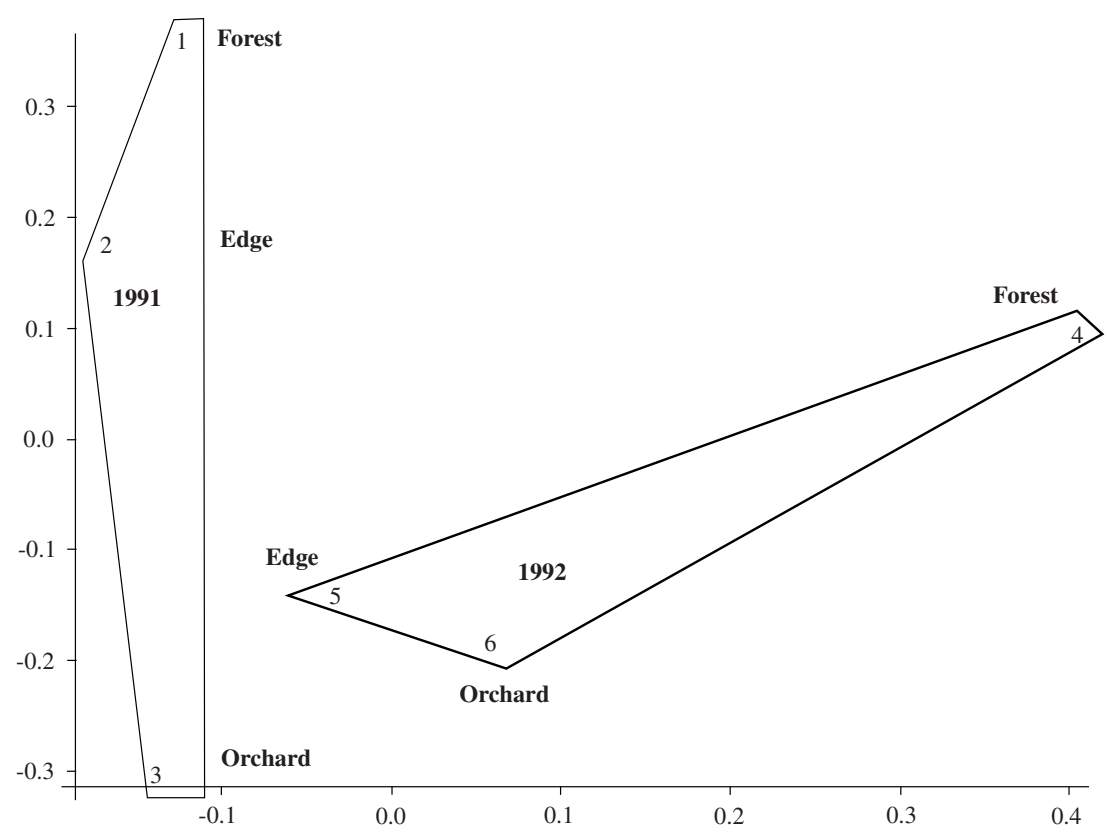

Fig. 3. Study of similarities of Neuropteroidea communities that appeared in different habitats (Malaise trapping), Nagykovácsi 1991-1992. PCoA method, Horn similarity

By exploring the individual Neuropteroidea species (Table 3) it was found that Hypochrysa elegans was strongly bound to the shrub level of closed oak forests while Micromus lanosus, Micromus angulatus, Hemerobius micans, Hemerobius lutescens and

\section{Table 3}

Linkage of different Neuropteroidea species to the shrub level of a canopied, closed oak forest, an untreated, abandoned mixed orchard and to an open, diverse, bushy edge between them; individual numbers. Malaise trapping, Nagykovácsi, 1991-1992

\begin{tabular}{lccc}
\hline Species & Forest & Edge & Orchard \\
\hline Hypochrysa elegans & 9 & 1 & 0 \\
Micromus lanosus & 13 & 8 & 1 \\
Micromus angulatus & 7 & 4 & 2 \\
Hemerobius micans & 7 & 2 & 1 \\
Hemerobius lutescens & 7 & 12 & 0 \\
Hemerobius humulinus & 5 & 8 & 0 \\
Dichrostigma flavipes & 12 & 25 & 7 \\
Chrysopa formosa & 5 & 17 & 5 \\
Chrysopa perla & 11 & 71 & 29 \\
Xanthostigma xanthostigma & 4 & 9 & 11 \\
Chrysoperla carnea & 9 & 11 & 13 \\
Dichochrysa prasina & 16 & 10 & 20 \\
\hline
\end{tabular}


Hemerobius humulinus occurred both in the forest shrub level and in the open edges. The species Dichrostigma flavipes, Chrysopa formosa, Chrysopa perla, Xanthostigma xanthostigma, Chrysoperla carnea and Dichochrysa prasina can be regarded as biotope generalists.

Passing beyond these tendencies it can be stated that Dichrostigma flavipes, Chrysopa formosa and Chrysopa perla attained their highest densities in open, diverse edge vegetation, although they occurred in other habitats as well.

\section{Discussion}

In our examinations of open forest edge, covered with diverse vegetation, interspersed with brushes the Neuropteroidea communities were larger and contained more species than the ones in the untreated orchard. This higher density resulted partly from the high numbers of Hemerobiids bound to oak forests and of other species that are linked to edge habitats, like Dichrostigma flavipes, Chrysopa formosa, Chrysopa perla. Higher species diversity was found in the shrub level of the oak forest and in the diverse brushland of the edge, however the highest diversity was found in the shrub level of the close canopied forest. Our results well fitted into the conclusions drawn by Szentkirályi (1989, 1992a, 1992b) in his reports on the Neuropteroidea of maize fields and Hemerobiidae of apple plantations. According to his data - in the vicinity of more diverse habitats - both the species number and diversity of communities increased. After abandoning the orchard the diversity of Neuropteroidea communities increased and became similar to the Neuropteroidea communities of the edge. However the species richness did not reach the ones of the other two habitats. The picture became further differentiated by our observations on the diversity of verge communities. The diversity of Neuropteroidea in the shrub level of closed, dense forests was significantly higher than the one of orchards. The scale parameters even surpassed the diversity values of mediocre and common species, compared with the values of forest edges.

As regards the similarities of communities it was concluded that in the different years and habitats no stable communities are formed; i.e. the composition of the Neuropteroidea communities are defined basically - besides the characteristics of their typical habitat - by other factors. It seems that in different years the environments are able to evolve Neuropteroidea communities of stable dominance order only in case of extremely homogenous surrounding vegetation (maize monoculture) and low diversity (Szentkirályi, 1989).

Our data concerning the preference of neuropteroid species to different habitats conform well to some results of Zeleny (1984). C. perla and C. formosa occurred along the edges of forests and woods, and C. carnea and Dichochrysa prasina were reported as common in oak forests and forest edges and also in orchards (Zeleny, 1984). 


\section{Acknowledgements}

We have to thank László Kazinczy and Mrs. L. Hornok for the maintenance of traps, Dr. Ferenc Szentkirályi for his valuable remarks made by reading our manuscript. The study itself has been supported by the OTKA Foundation (No. F23885).

\section{Literature}

Altieri, M. A. and Todd, J. W. (1981): Some influences of vegetational diversity on insect communities of Georgia soybean fields. Protection Ecology 3, 333-338.

Aspöck, H., Aspöck, U. and Hölzel, H. (unter Mitarbeit von H. Rausch) (1980): Die Neuropteran Europas. Eine zusammenfassende Darstellung der Systematik, Ökologie und Chorologie der Neuropteroidea (Megaloptera, Raphidioptera, Planipennia) Europas. 2 vols, 495 and 355 pp. Goecke and Evers, Krefeld, F. R. G.

Duelli, P. (1980a): Adaptive dispersal and appetitive flight in green lacewing Chrysopa carnea. Ecol. Ent. 5, 213-220.

Duelli, P. (1980b): Preovipository migration flights in green lacewing, Chrysopa carnea (Planipennia, Chrysopidae). Behav. Ecol. Sociobiol. 7, 239-246.

Honek, A. (1981): Aphidophagous Coccinellidae (Coleoptera) and Chrysopidae (Neuroptera) on three weeds: factors determining the composition of populations. Acta Ent. Bohemoslov. 78, 303-310.

Juillet, J. A. (1963): A comparison of 4 types of traps used for capturing flying insects. Can. J. Zool. 41, $219-223$.

Killington, F. J. (1936): A Monograph of the British Neuroptera. London Printed for the ray Society Vol. 1, $162 \mathrm{pp}$.

Moed, A. and Heads, M. J. (1987): Seasonality of arthropods caught a Malaise trap in mixed lowland forest of The Orongorongo Valley, New Zealand. New Zealand J. Zool. 14, 197-208.

Monserrat, V. J. and Marín, F. (1994): Plant substrate specificity of Iberian Chrysopidae (Insecta: Neuroptera). Acta Ecol. 15, 119-131.

Monserrat, V. J. and Marín, F. (1996): Plant substrate specificity of Iberian Hemerobiidae (Insecta: Neuroptera). J. Nat. Hist. 30, 775-787.

Móczár, L. (1967): Önműködő csapda repülő rovarok számára (Automatic trap for flying insects). Fol. Ent. Hung. 20, 214-222.

Paulian, M. and Andriescu, I. (1996): Chrysopidae and Hemerobiidae recorded from crops and adjacent natural habits in the Danube Delta, Rumania (Insecta: Neuroptera). Pure and Applied Research Neuropterology. Proceedings of the Fifth International Symposium on Neuropterology. Cairo, Egypt, 1994. In: Canard, M., Aspöck, H. and Mansell, M. W. (eds): Toulouse, France, 1996. pp. 203-206

Roberts, R. H. (1970): Colour of Malaise trap and the collection of Tabanidae. Mosq. News 30, 567-571.

Szentkirályi, F. (1989): Aphidophagus Chrysopid and Hemerobiid (Neuropteroidea) subguilds in different maize fields: Influence of vegetational diversity on subguild structure. Acta Phytopath. et Entomol. Hung. 24, 207-211.

Szentkirályi, F. (1992a): Spatio-temporal patterns of brown lacewings based on the Hungarian light trap network (Insecta: Neuroptera: Hemerobiidae). Pure and Applied Research Neuropterology. Proceedings of the Fifth International Symposium on Neuropterology. Cairo, Egypt, 1994. In: Canard, M., Aspöck, H. and Mansell, M. W. (eds): Toulouse, France, 1996. pp. 349-357.

Szentkirályi, F. (1992b): Brown lacewing (Neuropteroidea, Hemerobiidae) assemblages in Hungarian apple orchards. Acta Phytopath. Entomol. Hung. 27, pp. 601-604.

Szabó, S. and Szentkirályi, F. (1981): Communities of Chrysopidae and Hemerobiidae (Neuroptera) in some apple-orchards. Acta Phytopat. Hung. 16, 157-169.

Sziráki, Gy. (1996): Ecological investigations of the Neuropteroidea of oak forests in Hungary (Insecta: Raphidioptera, Neuroptera). Pure and Applied Research Neuropterology. Proceedings of the Fifth Interna- 
tional Symposium on Neuropterology. Cairo, Egypt, 1994. In: Canard, M., Aspöck, H. and Mansell, M. W. (eds): Toulouse, France, 1996. pp. 229-232.

Tóthmérész, B. (1995): Comparison of different methods for diversity ordering. Journal of Vegetation Science 6, 283-290.

Vidlicka, L. (1994): Flight activity of some Planipennia species. Biologia Bratislava, 49, pp. 729-737.

Vidlicka, L. (1995): Seasonal flight activity of Planipennia species at the Devinska Kobyla hill (West Carpatians). Biologia Bratislava, 50, pp. 151-156.

Zeleny, J. (1984): Chrysopid occurrence in West Palaeartic temperate forests and derived biotopes. Biology of Chrysopidae (Ed. by Canard, M., Séméria, Y., New, T. R.) pp. 151-160. 